\title{
A Brief Overview of the Specialty of Travel Medicine
}

\author{
Suresh Jude Antony ${ }^{1,}$, Catherine $\mathbf{H o}^{2}$ \\ ${ }^{1}$ International Travel Medicine Clinic of El Paso and Center for Infectious Diseases and Travel Medicine, El Paso, Texas, USA \\ ${ }^{2}$ University Medical Center of El Paso, Texas, USA
}

*Corresponding Author: Suresh Antony, International Travel Medicine Clinic of El Paso and Center for Infectious Diseases and Travel Medicine, El Paso, Texas, 1205 N Oregon, El Paso, Texas 79902, USA. Tel: 9155334900, Fax: 9155334902, Email: Suresh.Antony@att.net

Article History: Received: 27 Oct. 2015; Accepted: 19 Nov. 2015; Online Published: 10 Apr. 2016

Cite this article as: Antony SJ, Ho C. A brief overview of the specialty of travel medicine for the primary care physician. Int J Travel Med Glob Health. 2016;4(1):35-6.

\section{Dear Editor}

The knowledge base of Travel Medicine and the opportunities for disease control and elimination are being currently developed and described. New vaccines and preventive/curative drugs are becoming available as a result of well-controlled clinical trials. As new threats emerge (i.e. AIDS, Legionnaires' disease, and hemorrhagic colitis) and travelers embark on more complex itineraries, additional approaches are needed by those working in Travel Medicine.

\section{Epidemiology}

It is estimated that more than 1 billion travelers, including 68.3 million Americans, crossed international boundaries worldwide in 2014 [1, 2]. Whether related to tourism, humanitarian efforts, military leave, or globalization of industry, travelers are at increased health risk. The CDC approximates that 30 to 60 percent of these travelers, an estimated 15 million people, become ill due to their travels $[3,4]$.

\section{Immunizations for the International Traveler}

Immunizations for international travel are an important component of pre-travel medical care. Travelers should receive protection against vaccine-preventable exotic diseases, and immunity against common infectious diseases. Travel vaccine should be reviewed and updated as summarized in Table 1.

Table 1. Travel Vaccine Summary [5]

\begin{tabular}{|c|c|c|c|c|c|c|}
\hline Vaccine & Brand Name & Dose & Route & Schedule & Booster & Age \\
\hline \multirow[b]{2}{*}{ Hepatitis A (adult) } & Havrix & $1 \mathrm{~mL}$ & IM & $0,6-12$ months & None & $>19$ years \\
\hline & Vaqta & $1 \mathrm{~mL}$ & IM & $0,6-18$ months & None & $>19$ years \\
\hline Combined Hep A and Hep B & Twinrix & $1 \mathrm{~mL}$ & $\mathrm{IM}$ & 0,1 and 6 months & None & $>18$ years \\
\hline \multirow{2}{*}{ Hepatitis B (adult) } & Engerix-B & $1 \mathrm{~mL}$ & IM & 0,1 and 6 months & None & $>20$ years \\
\hline & Recombivax HB & $1 \mathrm{~mL}$ & IM & 0,1 and 6 months & None & $>20$ years \\
\hline Japanese Encephalitis & Ixiaro & $0.5 \mathrm{~mL}$ & IM & 0 and 28 days & $>1$ year after primary series & $>17$ years \\
\hline $\begin{array}{l}\text { Meningococcal conjugate } \\
\text { (MenACWY) }\end{array}$ & Menactra & $0.5 \mathrm{~mL}$ & $\mathrm{IM}$ & $\begin{array}{c}2 \text { doses separated by } 3 \text { months } \\
1 \text { dose }\end{array}$ & $\begin{array}{l}\text { Refer to CDC website for } \\
\text { specific indications }\end{array}$ & $\begin{array}{l}9-23 \text { years } \\
2-55 \text { years }\end{array}$ \\
\hline $\begin{array}{l}\text { Meningococcal polysaccharide } \\
\text { (MPSV4) }\end{array}$ & Menomune & $0.5 \mathrm{~mL}$ & $\mathrm{SC}$ & 1 dose & $\begin{array}{l}\text { Refer to CDC website for } \\
\text { specific indications }\end{array}$ & $>2$ years \\
\hline Inactivated polio (adult) & Ipol & $0.5 \mathrm{~mL}$ & $\mathrm{SC} / \mathrm{IM}$ & $\begin{array}{c}1 \text { dose at } \geq 18 \text { years, if patient has already had } \\
\text { an acceptable polio vaccine series }\end{array}$ & None & $>18$ years \\
\hline Rabies & Imovax & $1 \mathrm{~mL}$ & IM & Pre-exposure series: days 0,7 , and 21 or 28 & Refer to CDC website & $\begin{array}{l}\text { No age } \\
\text { restriction }\end{array}$ \\
\hline $\mathbf{V a}$ & Bran & Dose & Route & & $\mathrm{Bc}$ & Age \\
\hline I, live, attenuated & Vivtotif & 1 pill & Oral & 1 pill every other day for 4 doses & Every 5 years & $>6$ years \\
\hline Yellow fever & YF-Vax & $0.5 \mathrm{~mL}$ & $\mathrm{SC}$ & 1 dose & Every 10 years & $>9$ months \\
\hline
\end{tabular}

\section{Travel Medicine in Special Circumstances}

\section{A. The Pregnant Traveler}

In addition to the risks encountered by all travelers, a pregnant woman has a less-effective immune response that makes her more likely to have severe or potentially fatal complications from such infections as malaria, typhoid fever, and amebiasis. Moreover, she is at greater risk of acquiring new infections which may be potentially harmful to the fetus. In general, pregnant women without obstetric or medical complications can follow the same precautions and guidelines for air travel as the general population and can fly safely up to 36 weeks of gestation. The safest time to travel, however, is considered within the second trimester between 18-24 weeks [6].

If a pregnant woman must travel to a malarious area, she is recommended to cover exposed skin with light weight clothing and stay indoors between dusk and dawn.
Moreover, repellants containing up to $20 \%$ DEET are considered safe in pregnancy. One study showed that DEET caused no increase in low birth weight, prematurity, or congenital abnormalities. Although DEET was shown to cross the placenta ( $8 \%$ of cord samples), blood levels were low [7].

\section{B. Malaria}

Malaria infection is a potential risk in 97 countries. The World Health Organization estimates that 214 million cases of malaria occurred worldwide in 2015 with approximately 430,000 deaths, mostly of children in sub-Saharan Africa [8]. The diagnosis and treatment of malaria requires rapid case identification and initiation of specific and supportive therapy based on the parasitological and clinical classification of the patient. Healthcare providers advising travelers should assess the risk of malaria based on the traveler's itinerary and clinical condition, counsel to reduce 
contact with mosquitoes, prescribe appropriate chemoprophylaxis, and counsel regarding potential side effects and requirement for diagnosis and treatment if fever develops.

\section{Traveler's Diarrhea: Prevention and Treatment}

Traveler's diarrhea affects almost half of all persons traveling from developed to developing countries.

Because traveler's diarrhea is commonly self-limiting ( $90 \%$ of cases resolve within 1 week), oral rehydration with clear liquids is usually the main recommended treatment. If the traveler develops 3 or more loose stools within an eighthour period in association with vomiting, fever, abdominal cramps, or blood in stools, antimicrobial therapy for 3 to 5 days is recommended. The antibiotic of choice is usually a fluoroquinolone, but due to increasing cases of resistance, particularly with Campylobacter isolates, an alternative recommendation would be azithromycin [9].

\section{Fever and the Return Traveler}

Febrile infections can be fatal in travelers to tropical countries unless the patient seeks medical care in a timely manner and the physician has the skill to make a rapid diagnosis and prescribe appropriate therapy. In addition to the usual febrile illnesses present in temperate climates, the patient may contract an exotic infection such as malaria, infectious hepatitis, enteric fever, or dengue fever. The potential causes of fever in travelers are extensive.

\section{E. Skin Problems in Return Travelers}

A new lesion in a returning traveler often poses a difficult diagnostic problem for the clinician whose knowledge of geographical medicine is limited. To reach a diagnosis, the physician has to consider the location and style of travel, exposure to pathogens, length of stay, epidemiology, incubation period, and clinical presentation of dermatological diseases in the countries visited. As with any dermatological problem, the appearance of the presenting lesion should help to establish the differential diagnosis.

\section{F. Eosinophilia in Travelers}

Eosinophilia in travelers may be caused by infections acquired during travel. Infections with helminthic but not protozoan parasites are the most likely cause of eosinophilia, although other etiologies may warrant consideration.

\section{G. Intestinal Parasites in Return Travelers}

Travelers returning from third world countries may become infected with a variety of intestinal parasites. Although protozoan infections are more frequently seen, intestinal worms are also encountered. If considered in the differential diagnosis, these infections are usually readily diagnosed and treated.

\section{H. Sexually Transmitted Diseases in Travelers}

Sexually active travelers are at risk for a variety of sexually transmitted diseases, including traditional venereal infections such as gonorrhea, chlamydial urethritis, syphilis, chancroid, and herpes simplex infection. More recently, hepatitis $\mathrm{B}$, hepatitis $\mathrm{C}$, and human immunodeficiency virus also have been described. Penicillinase-producing strains of Neisseria gonorrhoeae are much more common in developing countries, particularly in Southeast Asia [10].

I. Tropical Diseases in Immigrants and Internationally Adopted Children

Immigrants, particularly those from the developing world, make up a significant number of the tropical disease cases seen in temperate climates. Internationally-adopted children are another high-risk group for which tropical and other infectious diseases must be considered in the evaluation.

\section{Conclusion}

Travel Medicine is a specialty that involves a broad-based knowledge of both tropical and non-tropical diseases. Travel Medicine specialists must be knowledgeable about the prevention, diagnosis, and treatment of these infections as well. Above all, the goal of a travel medicine specialist is to make sure that the traveler has a safe and healthy trip.

\section{References}

1. Reed CM. Travel recommendations for older adults. Clinics in geriatric medicine. 2007;23(3):687-713, ix.

2. Organization UNWT. . International tourism to continue robust growth in 2013: World Tourism Organization; 2013. Available from: http://www2.unwto.org/content/data-0.

3. Sanford CA, Jong EC. The travel and tropical medicine manual: Elsevier Health Sciences; 2008.

4. CDC. Travelers health: Airport: Screening and Monitoring Travelers to Prevent the Spread of Ebola [March 16, 2015]. Available from: http://wwwnc.cdc.gov/travel/diseases/ebola.

5. CDC. Travel Vaccine Summary Table 2015 [October 20, 2015]. Available from: http://wwwnc.cdc.gov/travel/yellowbook/2016/appendices/appendix -b-travel-vaccine-summary-table.

6. Rabinerson D, Ninio A, Glezerman M. [Air travel during pregnancy]. Harefuah. 2008;147(4):354-8, 72

7. McGready R, Hamilton KA, Simpson JA, Cho T, Luxemburger C, Edwards R, et al. Safety of the insect repellent N,N-diethyl-Mtoluamide (DEET) in pregnancy. The American journal of tropical medicine and hygiene. 2001;65(4):285-9.

8. Organization WH. Malaria: Information for travelers 2015 [October 17, 2015]. Available from: http://www.who.int/malaria/travellers/en/.

9. BA C. Travelers' Diarrhea: Centers for Disease Control and Prevention; 2015 [October 7, 2015]. Available from: http://wwwnc.cdc.gov/travel/yellowbook/2012/chapter-2-the-pretravel-consultation/travelers-diarrhea.htm

10. Zuckerman JN. Principles and practice of travel medicine: John Wiley \& Sons; 2002. 